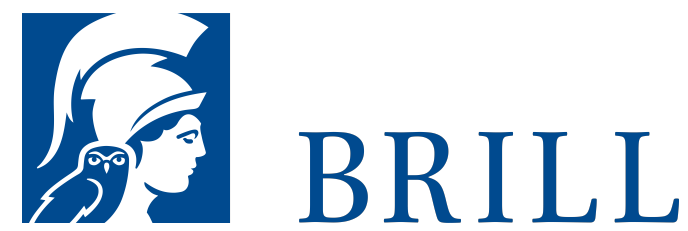

\title{
Die Grenzen staatlicher Legitimität
}

Eine philosophische Untersuchung zum Verhältnis von

Liberalismus und Perfektionismus

Author: Christine Bratu

Ist es legitim, wenn der Staat eine Auffassung zum guten Leben vertritt und seinen Bürgerinnen und Bürgern nahebringt? Oder muss sich ein legitimer Staat aus allen Fragen des Guten heraushalten? Oder darf sich ein Staat Auffassungen zum guten Leben zu eigen machen und legitimerweise befördern, wenn diese vor allen Bürgerinnen und Bürgern gerechtfertigt sind? Um diese Probleme dreht sich der Streit zwischen Perfektionismus, politischem Liberalismus und perfektionistischem Liberalismus. In vorliegendem Buch wird dieser Streit dargestellt und Stellung für den perfektionistischen Liberalismus bezogen. Dazu werden die Unterschiede zwischen den genannten Positionen herausgearbeitet ausgehend davon, wie diese die Minimalanforderung an staatliche Legitimität interpretieren. Insbesondere wird diskutiert, wie sich Perfektionismus sowie politischer und perfektionistischer Liberalismus zu den Fragen der Rechtfertigung normativer und evaluativer Urteile, des gerechtfertigten Pluralismus und der Grenzen gerechtfertigten Dissenses positionieren. Aus den Antworten, die sie auf diese Fragen geben, lässt sich schließlich auch ein neues Verständnis von Toleranz und staatlicher Neutralität im Liberalismus ableiten.

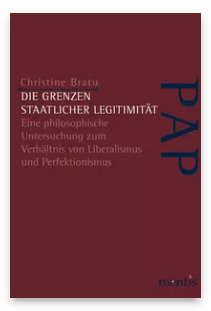

Pages: 251

Seiten

Language:

German

Subjects:

General, Philosophy

Publisher: Brill | mentis

E-Book (PDF)

Released online:

31 Jul 2014

ISBN: $978-3^{-}$

$89785^{-895-4}$

List price

Paperback

Publication date:

31 Jul 2014

ISBN: 978-3-

89785-227-3

List price 
For more information see brill.com

Order information: Order online at brill.com +44330 333 0049 | customerservices@brill.com Submission information: brill.com/authors

Titles published by Brill | Fink, Brill | mentis or Brill | Schöningh: +49(o)715413279216| brill@brocom.de 